\title{
COPD: Is there evidence to support a role for resistance training in improving measurable health-related quality of life in pulmonary rehabilitation?
}

\author{
S J Semple, DTech
}

A J McKune, DTech

Department of Sport, Rehabilitation and Dental Sciences, Tshwane University of Technology, Pretoria

\begin{abstract}
Chronic obstructive pulmonary disease (COPD) is one of the leading causes of morbidity and mortality. As such, the disease places a significant burden on health care services. Although the pathogenesis of COPD is complex, progressive airflow limitation and a chronic inflammatory response are two hallmark characteristics of the disease. In addition, systemic manifestations such as peripheral muscle dysfunction have recently received considerable attention in the literature. Pulmonary rehabilitation is an evidence-based multidisciplinary intervention that has been shown to produce clinically relevant outcomes. One important component of rehabilitation is exercise. With the majority of COPD patients presenting with muscle weakness and exercise intolerance, the inclusion of resistance training into a pulmonary rehabilitation programme would seem appropriate. Compared with other exercise/training modalities only a small number of studies have investigated the effects of resistance training in COPD patients. Although further research is required to identify the optimal mode, intensity and frequency, it appears that resistance training may prove to be a valuable intervention for COPD patients enrolled in pulmonary rehabilitation programmes.
\end{abstract}

\section{CORRESPONDENCE:}

\section{Stuart Semple}

Department of Sport, Rehabilitation and Dental Sciences

Tshwane University of Technology

Private Bag X680

Pretoria

0001

Tel: (012) 382-4324

Fax: (012) 382-5801

Cell: 0824524461

E-mail: semplesj@tut.ac.za

\section{Introduction}

Chronic obstructive pulmonary disease (COPD) is a major cause of disability and premature death and as a result is regarded as global health priority. ${ }^{7}$ While the relative contribution of coronary heart disease and stroke towards death is on the decline, mortality from COPD is on the increase. ${ }^{17}$ This trend has prompted an increase in the number of studies investigating the efficacy of different treatment modalities within pulmonary rehabilitation (PR), and has resulted in the synthesis of a number of consensus statements and clinical guidelines by various associations.

PR can be defined as 'an evidence-based multidisciplinary and comprehensive intervention for patients with chronic respiratory disease who are symptomatic and often have decreased daily life activities. Integrated into individualised treatment of the patient, pulmonary rehabilitation is designed to reduce symptoms, optimise functional status, increase participation, and reduce health care costs through stabilising or reversing systemic manifestations of the disease. ${ }^{37} \mathrm{~A}$ number of deleterious effects have been associated with COPD and include, among others, social isolation, exercise deconditioning, depression, muscle wasting and impaired health-related quality of life (HRQL). ${ }^{9,55,56}$ Consequently, PR programmes should aim to treat the patient holistically. This invariably means adopting an interdisciplinary approach where various health care professionals address the different components represented in Fig. 1.

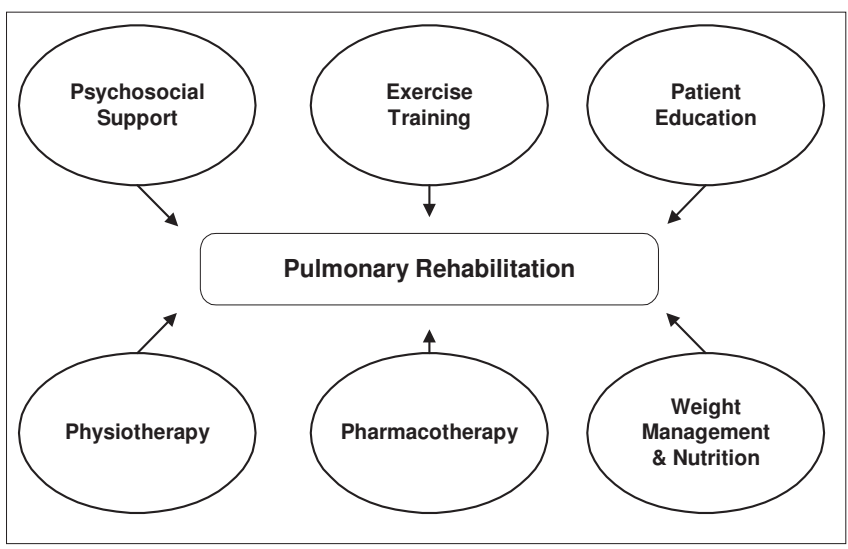

Fig. 1. Fundamental components of pulmonary rehabilitation programmes. 


\section{COPD pathophysiology}

COPD is 'a disease state characterised by airflow limitation that is not fully reversible. The airflow limitation is usually both progressive and associated with an abnormal inflammatory response of the lungs to noxious particles or gases'. ${ }^{35}$ Noxious stimuli such as viral infections and inhaled irritants, especially cigarette smoking, results in irritation of the respiratory tract mucosa. It has been suggested that this continual irritation induces epithelial injury and thus provides the stimulus for inflammatory infiltrate. ${ }^{11}$ Dominance of a chronic inflammatory state within the mucosa results in mucus hypersecretion, ciliary dysfunction, oedema and structural changes such as fibrosis and loss of parenchymal integrity. ${ }^{38,45}$ The resultant swelling of the mucosa and subsequent narrowing of the lumen result in airflow obstruction and air trapping/hyperinflation. The inhibition of normal gaseous exchange, i.e. impaired lung function, results in hypoxaemia, which in turn induces dyspnoea, a factor that may deter patients from participating in physical activity. ${ }^{1,10}$

\section{Skeletal muscle dysfunction}

Inflammatory sequelae are central to the pathogenesis of COPD, and while it has traditionally been defined as a disease of the airways, significant systemic factors manifest in COPD patients, making it a multi-component disease. ${ }^{60} \mathrm{~A}$ common finding in patients suffering from COPD is muscle weakness and a reduction in muscle mass. ${ }^{3,23,45}$ It appears that lower limb muscles are more affected than those of the upper limbs. ${ }^{3,23}$ Potential factors contributing to muscle wasting in COPD patients are represented in Fig. 2. It should be noted that these factors may all contribute in varying degrees towards skeletal muscle dysfunction. The reduction in fat free mass in COPD patients may negatively impact on 'physical function, health status and survival'. ${ }^{25}$ Recently, muscle dysfunction has received considerable attention within the literature as a hallmark manifestation of COPD. Skeletal muscle comprises approximately $73 \%$ of body mass. ${ }^{31}$ In addition to affecting $\mathrm{HRQL}$, dysfunction of skeletal muscle has important implications for exercise tolerance and physical rehabilitation. Physiological or structural alterations that have been documented in the skeletal muscle of COPD patients include: increased proportion of type II fibres; ${ }^{47}$ reductions in myosin heavy chain type I isoforms; ${ }^{34}$ reductions in uncoupling protein-3.mRNA (protects against mitochondrial damage) and intramyocellular triglyceride in oxidative fibres; ${ }^{46}$ reduced vastus lateralis mitochondrial density; ${ }^{18}$ reductions in crosssectional area of type IIX fibres and increased fibrosis; ${ }^{19}$ reductions in oxidative enzymes (correlated with number of type I fibres) and lowered oxidative capacity in type II fibres; ${ }^{20}$ decreased muscle capillarity ${ }^{26}$ and reductions in peroxisome proliferator-activated receptors (involved in mitochondrial biogenesis). ${ }^{43}$ Gosker et al. ${ }^{21}$ recently confirmed that the severity of COPD is associated with reductions in the proportion of type I fibres. The aforementioned factors together with the finding that lactic acidosis occurs earlier during exercise in COPD patients compared with healthy subjects, ${ }^{33}$ may partly explain why COPD patients fatigue quicker and experience exercise intolerance. This in turn may deter individuals from participating in physical activity and promote physical deconditioning, ultimately fuelling the progression of COPD (Fig. 3).

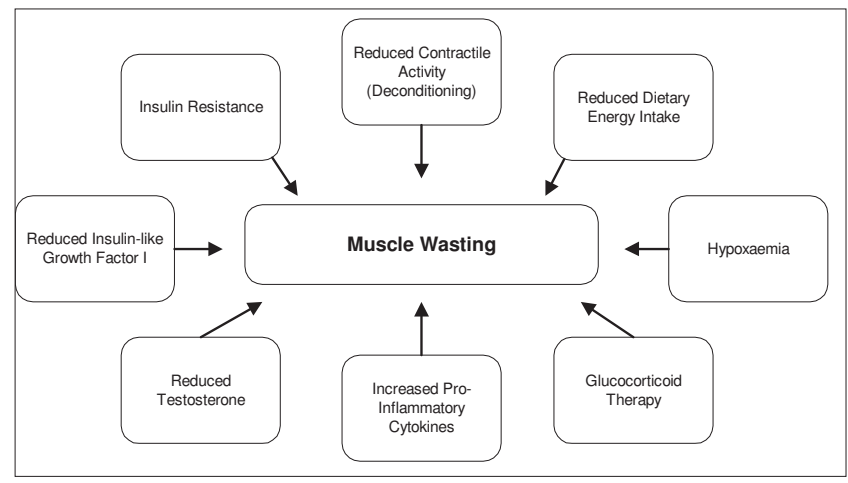

Fig. 2. Factors involved in muscle wasting in COPD (adapted from Jagoe and Engelen ${ }^{(25)}$ ).

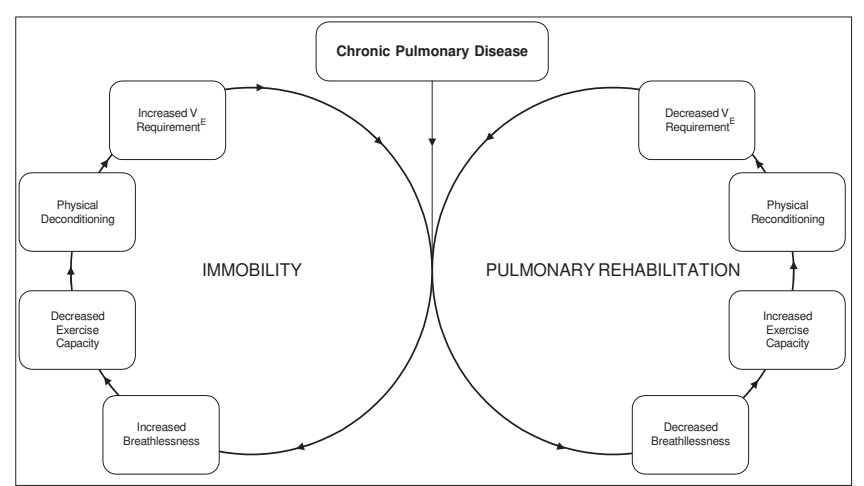

Fig. 3. Cycle of disabling breathlessness, physical inactivity and deconditioning in COPD. (From Cooper CB. Exercise in chronic pulmonary disease: limitations and rehabilitation. Med Sci Sports Exerc 2001; 33(7): S643S646, with permission.)

\section{Exercise and pulmonary rehabilitation}

Pulmonary rehabilitation (PR) programmes can improve HRQL in COPD patients. ${ }^{12}$ Exercise intervention is arguably one of the most important components of a PR programme. ${ }^{30,37,44,57,58}$ Exercise intolerance in COPD patients cannot be solely attributed to ventilatory limitations. ${ }^{52}$ Rather, it has been proposed that the limitations are multifactorial and include metabolic and gas exchange abnormalities, peripheral muscle dysfunction, cardiac impairment and exertional symptoms. ${ }^{39}$ A number of studies have shown the positive effects that exercise training may exert on a variety of clinical symptoms in COPD patients. The mode of exercise most extensively researched has been that of endurance/aerobic type activities. In addition, a substantial number of investigations have been conducted into the effects of inspiratory and expiratory ventilatory training in COPD patients. Although most COPD patients experience muscle weakness, comparatively fewer studies have investigated resistance-training 


\begin{tabular}{|c|c|c|c|}
\hline Reference & Participants & Intervention & Significant alterations $(p<0.05)$ \\
\hline Simpson et al. ${ }^{49}$ & $\begin{array}{l}\text { COPD patients }(N=14 \text {, } \\
\text { mean } \mathrm{FEV}_{1} 39.5 \% \text { predicted, } \\
\text { mean age } 73 \text { years })\end{array}$ & $\begin{array}{l}\text { Weightlifting } 3 \times / \text { wk for } 8 \text { wks } 3 \times 10 \text { reps; } \\
\text { workload increased from } 50 \% \text { of } 1 \text { RM } \\
\text { in week } 1 \text { to } 85 \% \text { of } 1 \text { RM in week } 8 \text {; } \\
1 \text { RM re-evaluated every } 6 \text { session; } \\
\text { single arm curl, leg press and leg extension }\end{array}$ & $\begin{array}{l}\text { Increased patients' mastery over the } \\
\text { demands of daily living. Improvements } \\
\text { in fatigue and dyspnoea; time to fatigue } \\
\text { during cycling at } 80 \% \text { of maximum } \\
\text { improved; } 1 \text { RM improvements in arm } \\
\text { curl }(33 \%) \text {, leg press ( } 16 \%) \text { and leg } \\
\text { extension ( } 44 \%)\end{array}$ \\
\hline Clark et al. ${ }^{8}$ & $\begin{array}{l}\text { COPD patients }(N=26 \text {, } \\
\text { mean } \mathrm{FEV}_{1} 76 \% \\
\text { predicted, mean age } 51 \\
\text { years) }\end{array}$ & $\begin{array}{l}\text { Dynamic weight training exercises } \\
(N=8) .2 x / \text { wk for } 12 \text { wks; workload } \\
70 \% \text { of } 1 \mathrm{RM} \text { for } 12 \text { wks; after week } 6 \text {, } \\
1 \mathrm{RM} \text { assessed and workload } \\
\text { adjusted to 'new' } 70 \% \text {; upper and } \\
\text { lower body exercises }\end{array}$ & $\begin{array}{l}\text { Increases in maximum weight lifted } \\
\text { (isotonic) observed for } 5 \text { out of the } \\
8 \text { exercises; sustained (60s) isokinetic } \\
\text { muscle work, endurance work (joules) } \\
\text { and maximal tidal volume improved }\end{array}$ \\
\hline Spruit et al. ${ }^{50}$ & $\begin{array}{l}\text { COPD patients }(\mathrm{N}=24, \\
\text { mean } \mathrm{FEV}_{1} 40 \% \\
\text { predicted, mean age } 64 \\
\text { years) }\end{array}$ & $\begin{array}{l}\text { Dynamic strengthening exercises } \\
\text { (machines \& pulleys). } 3 x / \text { wk for } 12 \\
\text { wks; initial intensity } 70 \% \text { of } 1 \text { RM ( } 3 x \\
8 \text { reps); weekly } \uparrow 5 \% \text { of } 1 \text { RM }\end{array}$ & $\begin{array}{l}\text { Increases in knee extension, knee } \\
\text { flexion, shoulder abduction, and } \\
\text { elbow flexion force; } 38 \% \text { improvement } \\
\text { in 6MWD; increased peak watts during } \\
\text { an incremental cycling test; improved } \\
\text { HRQL }\end{array}$ \\
\hline Ortega et al. ${ }^{40}$ & $\begin{array}{l}\text { COPD patients ( } N=17 \text {, } \\
\text { mean } \mathrm{FEV}_{1} 40 \% \\
\text { predicted, mean age } 66 \\
\text { years) }\end{array}$ & $\begin{array}{l}\text { Dynamic strengthening exercises } \\
\text { ('gymnastics apparatus') } 3 \times \text { /wk for } 12 \\
\text { wks; } 4 \text { x } 6-8 \text { reps, } 70-85 \% \text { of } 1 \mathrm{RM} \\
\text { RM testing conducted every } 2 \\
\text { wks to adjust workload; upper and } \\
\text { lower body exercises }\end{array}$ & $\begin{array}{l}\text { Shuttle walking test (m) and endurance } \\
\text { test (min) improved; strength } \\
\text { measurements }(\mathrm{kg}) \text { in chest pull, } \\
\text { butterfly, neck press, leg flexion and } \\
\text { leg extension improved; dyspnoea } \\
\text { and HRQL improved }\end{array}$ \\
\hline Wright et al. ${ }^{61}$ & $\begin{array}{l}\text { COPD patients ( } N=20 \text {, } \\
\text { mean } F E V_{1} 54 \% \text { predicted, } \\
\text { mean age } 56 \text { years) }\end{array}$ & $\begin{array}{l}\text { Upper and lower body dynamic strength/machine } \\
\text { exercises } 2 \times / \text { wk for } 2 \text { wks; } 3 \times 12 \text { reps (adaptation } \\
\text { phase - submaximal intensity), then } 3 \times / \text { wk } \\
2-4 \times 10 \text { reps, for } 5 \text { wks, then } 3 / \text { wk } 2-4 \times 8-10 \text { reps } \\
\text { for } 5 \text { wks (focus on intensive eccentrics) }\end{array}$ & $\begin{array}{l}\text { Cycle ergometry performance } \\
\text { improved in training group } \\
(18.7 \%) \text {; improved } \mathrm{HRQL}\end{array}$ \\
\hline Kongsgaard et al. ${ }^{29}$ & $\begin{array}{l}\text { COPD patients ( } N=6 \text {, } \\
\text { mean } F E V_{1} 48 \% \text { predicted, } \\
\text { mean age } 71 \text { years) }\end{array}$ & $\begin{array}{l}\text { Progressive resistance training } 2 \times / \text { wk } \\
\text { for } 12 \text { wks; } 4 \text { x } 8 \text { reps ( } 2-3 \text { min between sets), } \\
80 \% \text { of } 1 \mathrm{RM} \text {; leg press, knee extension, } \\
\text { knee flexion; workload adjusted weekly }\end{array}$ & $\begin{array}{l}\text { ADL (walking } 400 \mathrm{~m} \text {, climbing stairs, } \\
\text { carrying } 5 \mathrm{~kg} \text { ) improved; self-reported } \\
\text { health improved, knee extension } \\
\text { and trunk flexion strength improved, } \\
\text { gait time ( } 30 \mathrm{~m} \text { ) and stair climbing } \\
\text { time decreased }\end{array}$ \\
\hline Hoff et al. ${ }^{24}$ & $\begin{array}{l}\text { COPD patients ( } N=6 \text {, } \\
\text { mean } \mathrm{FEV}_{1} 32 \% \text { predicted, } \\
\text { mean age } 62 \text { years) }\end{array}$ & $\begin{array}{l}\text { Horizontal leg press, } 8 \text { wk ( } 24 \text { sessions); } \\
4 \times 5 \text { reps, } 85-90 \% \text { of } 1 \mathrm{RM} ; 2.5 \mathrm{~kg} \text { progressions } \\
\text { implemented when subject could } \\
\text { perform more than } 5 \text { reps }\end{array}$ & $\begin{array}{l}\text { Dynamic rate of force development, } \\
1 \mathrm{RM} \text { and peak static force improved; } \\
\text { mechanical efficiency of cycling } \\
(40 \mathrm{~W}) \text { improved by } 31 \% \text {; RPE at } \\
40 \mathrm{~W} \text { reduced; improved } \mathrm{FEV}_{1}(21 \%) \text {, } \\
\text { FVC }\end{array}$ \\
\hline
\end{tabular}

effects in COPD patients as a modality in isolation. To the best of the authors' knowledge Table I contains the only studies that have documented the effects of resistance training in COPD patients. Some of these studies compared a resistance training group versus other interventions. However, the alterations summarised in Table I represent the effects of only resistance training and no other combined intervention.
COPD is not just a disease of the respiratory system. It is now well established that the skeletal muscles of COPD patients are both morphologically and functionally different from those of healthy individuals. ${ }^{19}$ The extent of the changes is so pronounced that COPD has been termed a muscle disease. ${ }^{57}$ Since exercise intolerance in COPD cannot be attributed to ventilatory limitations alone, and skeletal muscle 
dysfunction is a significant component of the disease, it would seem appropriate to incorporate resistance training into a PR programme. Resistance training 'involves the voluntary activation of specific skeletal muscles against some form of external resistance, which is provided by body mass, free weights (barbells and dumbbells), or a variety of exercise modalities (machines, springs, elastic bands, manual resistance etc.)'. ${ }^{59}$ The potential benefits of resistance training in apparently healthy individuals have been reviewed by a number of authors, and includes improvements in muscle strength, increases in muscle size (hypertrophy), increases in protein synthesis, reductions in visceral fat, and reductions in risk factors associated with chronic disease such as diabetes, cardiovascular disease, cancer and osteoporosis. ${ }^{14,59}$ The latter may prove beneficial for COPD patients, as many suffer from co-morbid conditions.

It is arguable that any intervention employed within a PR programme should directly or indirectly serve to improve the patient's quality of life. With this in mind, the question should be asked: do improvements in strength conferred from resistance training translate to improvements in functional capacity in COPD patients? There is evidence to support the value of resistance training in reducing functional limitations in healthy individuals. ${ }^{5}$ From the randomised controlled studies summarised in Table I, it is apparent that strength of specific muscles improved in 6 out of 6 of the studies in which it was measured. In addition, improved activities of daily living, the mastery thereof, and/or HRQL were significantly enhanced in 5 of the 7 studies. HRQL is most commonly measured using the Chronic Respiratory Disease Questionnaire. ${ }^{22}$ The questionnaire, which has been validated for use in a clinical setting, measures four categories pertaining to physical and emotional discomfort during normal daily activities. The patient's responses are scored on a 7-point Likert scale for categories of dyspnoea, fatigue, emotional function and mastery. Although the interventions among the studies differed, all used patients with COPD. It remains to be seen what effect resistance training may have on patients who have other pulmonary conditions/disorders. All the studies implemented the principle of progression and the training intensity was based on nothing 'lighter' than $70 \%$ of the subject's one repetition maximum. No authors reported adverse effects of the training despite some interventions being of a high intensity ( $\geq 85 \%$ of $1 \mathrm{RM}$ ). Improvements in maximal tidal volume and $\mathrm{FEV}_{1}$ in the studies by Clark et $\mathrm{al}^{8}$ and Hof et al. ${ }^{24}$ respectively, were the only documented changes in pulmonary function parameters. Although FEV 1 is important in the diagnosis of COPD, it cannot be reliably correlated with exercise capacity, dsypnea or HRQL. ${ }^{10}$ Thus, the lack of improvements in pulmonary function parameters following resistance training interventions may not be clinically significant. A potential limiting factor in terms of interpreting the efficacy of resistance training in the PR programmes referenced in Table I is that there are large discrepancies in the ages of the participants. In addition, the studies fail to indicate what the participant's level of activity and co-morbid status was before being diagnosed with COPD. This implies that the participants utilised in the studies may have shown favourable benefits from the training interventions because they may have been sedentary (or active) for many years prior to their diagnosis. Thus, the 'true' benefits conferred by the resistance training are difficult to quantify accurately.

More studies have been conducted on the effects of endurance training in PR than any other modality. ${ }^{9}$ In addition to the studies referenced in Table I, a number of researchers have looked at a combination of strength-endurance interventions in COPD patients. ${ }^{2,4,3,28,32}$ Results from these studies do in some instances support a combined programme over endurance or resistance training alone. The reported additive effects of combined interventions (resistance and endurance) in some studies have gained support for its incorporation into rehabilitation programmes. ${ }^{4,28,37,56}$ When summarising randomised controlled trials comparing different exercise modes on COPD patients, Puhan et al. ${ }^{42}$ reported that 'strength exercise led to larger improvements of $\mathrm{HRQL}$ than endurance exercise'. Although only 4 studies (strength v. endurance) were compared for the purposes of the review, the results do highlight the potential therapeutic value of strength/ resistance training. An advantage of resistance training is that it stresses the cardiorespiratory system less when compared with traditional aerobic exercise (cycling, walking, jogging). The reduced metabolic demand of resistance training means lower levels of lactate accumulation and dyspnoea, factors that would encourage patients to adhere to physical training interventions.

\section{Resistance training and molecular adaptations in skeletal muscle}

It may be counter-intuitive to recommend resistance training to COPD patients due to the shift from a slow to fast twitch phenotype, observed in their skeletal muscle. ${ }^{21,34,47}$ A shift in distribution from slow to fast twitch fibres gives rise to altered activities of key oxidative and glycolytic enzymes ${ }^{62}$ that may decrease oxidative capacity and increase the risk of developing insulin resistance. ${ }^{48}$ Whether resistance training exacerbates this phenotype switch, decreasing functional and oxidative capacity further, or maintains the status quo, has not been determined in COPD patients. In addition, it was recently hypothesised that resistance training may only induce brief 5'AMP-activated protein kinase (AMPK) activation (possibly not at all), resulting in limited AMPK-dependent adaptations such as mitochondrial biogenesis. ${ }^{51}$ With the skeletal muscle of COPD patients already exhibiting reduced mitochondrial biogenesis, oxidative enzymes and oxidative capacity, ${ }^{18,43}$ the possibility that resistance training may exacerbate this situation requires clarification.

In contrast to the above possible detrimental effects of resistance training for COPD patients, recent research has shown that acute resistance training promotes skeletal muscle angiogenesis and hence capillarity. ${ }^{6,16,54}$ This finding provides support for the use of resistance training in COPD patients, who display decreased muscle capillarity. ${ }^{26}$ Specifically, research has shown that vascular endothelial 
growth factor (VEGF) mRNA is increased 2.9-fold above rest 24 hours after resistance exercise in young and aged men as determined by pooled mRNA microarray analysis. ${ }^{27}$ In the most recent study, acute resistance exercise (3 sets of 10 repetitions knee extension at $60-80 \%$ of 1 RM, 2 minutes' rest between each set) significantly increased skeletal muscle (vastus lateralis) VEGF mRNA and protein, plasma VEGF protein and skeletal muscle VEGF receptor (KDR and Nrp1) mRNA in sedentary, young (range 24 - 32 years of age) individuals ( 6 men, 1 woman). The authors concluded that early angiogenic signalling for VEGF is increased by acute resistance exercise although additional research is required to determine the signal transduction pathways responsible for up-regulating the angiogenesis growth factors and receptors. ${ }^{16}$ It remains to be determined whether the increased skeletal muscle angiogenesis/capillarity induced by resistance training in healthy young individuals also occurs in COPD patients, who are typically older. In addition, research is also required to determine whether resistance training induced increases in skeletal muscle angiogenesis/ capillarity has any beneficial effect on the functional capacity and HRQL of COPD patients.

\section{Anti-inflammatory nature of resistance training?}

From the above discussion it can be seen that the precise molecular mechanisms in skeletal muscle that may underlie beneficial or detrimental resistance training transfers for PR patients are complex, with many areas requiring further research.

An additional area of research that is currently receiving worldwide attention relates to the possible anti-inflammatory effect of exercise. With COPD exhibiting a strong inflammatory component, ${ }^{35}$ it may just be that exercise serves to attenuate the chronic inflammatory response in these patients. Oxidative stress (free radical species) modulates aspects of inflammatory-induced alterations in skeletal muscle function. ${ }^{53}$ Eight weeks of aerobic exercise (cycle ergometry) 3 times per week for 60 minutes has been shown to reduce exerciseinduced oxidative damage in COPD patients. ${ }^{41}$ Exerciseinduced elevations in cytokines (particularly interleukin-6) have been implicated as potential role players involved in inducing the anti-inflammatory effect associated with exercise. ${ }^{15}$ Whether resistance training promotes a downregulation in oxidative/inflammatory responses remains to be elucidated. High doses of corticosteroids have been shown to induce skeletal myopathies. ${ }^{36}$ If indeed the mechanism by which exercise imparts favourable health benefits is antiinflammatory sequelae, then it may reduce or impact on the patient's reliance on medications. This in turn could affect $\mathrm{HRQL}$ as certain medications have undesirable side-effects.

\section{Conclusion}

Although guidelines have been established, ${ }^{52}$ the optimal mode, frequency and intensity of resistance training (especially among differing pulmonary pathologies) still requires further investigation. This is important in order to establish the true efficacy of resistance training for COPD patients. This in turn would prevent rehabilitation practitioners from prescrib- ing to or implementing practices that are not supported by evidence. Recently, evidence-based clinical guidelines jointly generated by the American College of Chest Physicians (ACCP) and the American Association of Cardiovascular and Pulmonary Rehabilitation (AACVPR) reject the inclusion of inspiratory training as part of a PR programme based on lack of evidence. ${ }^{44}$ This highlights the fact that although papers have been published advocating the use of inspiratory training in COPD patients, further research is still required. Similarly, further research is still required to show that resistance training may reduce and/or reverse muscle wasting and dysfunction. Currently, no studies have been conducted in which muscle biopsies have been performed to determine if cellular/biochemical changes occur as a result of strength training in COPD patients. ${ }^{44}$

Based on the results of studies that have investigated the effects of resistance training on COPD patients, it seems that resistance training may indeed contribute favourably to the exercise training component within a PR programme. This 'sentiment' is acknowledged by the ACCP and the AACVPR. Although 'clinicians underestimated the degree to which skeletal muscle weakness contributes to patient morbidity'. ${ }^{53}$ it seems that within the literature more and more authors are promoting the inclusion of resistance training within PR programmes. Many argue that a combination of endurance and strength training would be most beneficial for the patient. Future studies are required to shed light on the extent to which resistance training may impact on functional capacity and HRQL in COPD patients. In addition, studies are required to investigate the role of resistance training in altering inflammatory responses as well as beneficial or detrimental molecular pathways within the skeletal muscle of COPD patients.

\section{Acknowledgements}

Thanks are due to Professor Lucille Smith for critically reviewing the manuscript and Mandi Semple for assistance with the figures.

\section{REFERENCES}

1. Anzueto A. Clinical course of chronic obstructive pulmonary disease: Review of therapeutic interventions. Am J Med 2006; 119: S46-S53.

2. Arnardottir RH, Sorensen $S$, Ringqvist I, Larsson $\mathrm{K}$. Two different training programmes for patients with COPD: A randomised study with 1-year follow up. Respir Med 2006; 100:130-9.

3. Bernard S, LeBlanc P, Whittom F, et al. Peripheral muscle weakness in patients with chronic obstructive pulmonary disease. Am J Respir Crit Care Med 1998; 158: 629-34.

4. Bernard S, Whittom F, LeBlanc $P$, et al. Aerobic and strength training in patients with chronic obstructive pulmonary disease. Am J Respir Crit Care Med 1999; 159: 896-901.

5. Brill PA, Macera CA, Davis DR, Blair SN, Gordon N. Muscular strength and physical function. Med Sci Sports Exerc 2000; 32: 412-6.

6. Campos GE, Luecke TJ, Wendeln HK, et al. Muscle adaptations in response to three different resistance-training regimens: specificity of repetition maximum training zones. Eur J Appl Physiol 2002; 88: 50-60.

7. Cazzola M, Donner C, Hanania N. One hundred years of chronic obstructive pulmonary disease. Respir Med 2007; 101: 1049-65.

8. Clark CJ, Cochrane LM, Mackay E, Paton B. Skeletal muscle strength and endurance in patients with mild COPD and the effects of weight training. Eur Respir J 2000; 15: 92-7.

9. Clini E, Costi S, Ramagnoli M, Florini F. Rehabilitation of COPD patients: which training modality. Monaldi Arch Chest Dis 2004; 61: 167-73. 
10. Cooper CB. The connection between chronic obstructive pulmonary disease symptoms and hyperinflation and its impact on exercise and function. Am J Med 2006; 119: S21-S31.

11. Cosio Piqueras MG, Cosio MG. Disease of the airways in chronic obstructive pulmonary disease. Eur Respir J 2001; 18: 41S-49S.

12. Finnerty JP, Keeping I, Bullough I, Jones J. The effectiveness of outpatien pulmonary rehabilitation in chronic lung disease. A randomised controlled trial. Chest 2001; 119: 1705-10.

13. Franssen FM, Broekhuizen R, Janssen PP, Wouters EFM, Schols AMW. Effects of whole-body exercise training on body composition and functional capacity in normal weight patients with COPD. Chest 2004; 125(6): 2021-28.

14. Frontera WR, Xavier B. The benefits of strength training in the elderly. Sci Sports 2002; 17: 109-16.

15. Garrod R, Ansley P, Canavan J, Jewell A. Exercise and the inflammatory response in chronic obstructive pulmonary disease (COPD) - Does training confer anti-inflammatory properties in COPD? Med Hypothesis 2007; 68 291-8.

16. Gavin TP, Drew JL, Kubik CJ, Pofahl WE, Hickner RC. Acute resistance exercise increases skeletal muscle angiogenic growth factor expression. Acta Physiol 2007; 191: 139-46.

17. GOLD. Global Strategy for the Diagnosis, Management and Prevention of COPD, Global Initiative for Chronic Obstructive Lung Disease Available from: http://www.goldcopd.org.(accessed 24 September 2007).

18. Gosker HR, Hesselink MKC, Duimel H, Ward KA,Schols AMWJ. Reduced mitochondrial density in the vastus lateralis muscle of patients with COPD. Eur Respir J 2007; 30: 73-9.

19. Gosker HR, Kubat B, Schaart G, van der Vusse GJ, Wouters EFM, Schols AMWJ. Myopathological features in skeletal muscle of patients with chronic obstructive pulmonary disease. Eur Respir J 2003; 22: 280-5.

20. Gosker HR, van Mameren H, van Dijk PJ, et al. Skeletal muscle fibre type shifting and metabollic profile in patients with chronic obstructive pulmonary disease. Eur Respir J 2002; 19: 617-25.

21. Gosker HR, Zeegers M, Wouters E, Schols AMWJ. Muscle fibre type shifting in the vastus lateralis of patients with COPD is associated with disease severity: a systematic review and meta-analysis. Thorax 2007; 62(11): 944-9.

22. Guyatt GH, Berman LB, Townsend M, Pugsley SO, Chambers LW. A measure of quality of life for clinical trials in chronic lung disease. Thorax 1987; 42: $773-8$

23. Hamilton AL, Killian K, Summers E, Jones NL. Muscle strength, symptom intensity, and exercise capacity in patients with cardiorespiratory disorders. Am J Respir Crit Care Med 1995; 152: 2021-31.

24.Hoff J, Tjonna AE, Steinshamn S, Hoydal M, Richardson R, Helgerud J. Maximal strength training of the legs in COPD: A therapy for mechanical ineffciency. Med Sci Sports Exerc 2007; 39: 220-6.

25. Jagoe RT, Engelen MPKJ. Muscle wasting and changes in muscle protein metabolism in chronic obstructive pulmonary disease. Eur Respir J 2003; 22: 52S-63S.

26. Jobin J, Maltais F, Doyon JF, et al. Chronic obstructive pulmonary disease capillarity and fibre-type characteristics of skeletal muscle. J Cardiopulmon Rehabil 1998; 18: 432-7.

27. Jozsi AC, Dupont-Versteegden EE, Taylor-Jones JM, et al. Aged human muscle demonstrates an altered gene expression profile consistent with an impaired response to exercise. Mech Ageing Dev 2000; 120: 45-56.

28. Kamahara K, Homma T, Naito K, et al. Circuit training for elderly patients with chronic obstructive pulmonary disease: a preliminary study. Arch Geronto Geriatrics 2004; 39: 103-10.

29. Kongsgaard M, Backer V, Jorgensen K, Kjaer M,Beyer N. Heavy resistance training increases muscle size, strength and physical function in elderly male COPD-patients - a pilot study. Respir Med 2004; 98: 1000-7.

30. Lacasse Y, Guyatt GH, Goldstein RS. The components of a respiratory rehabilitation program: a systematic overview. Chest 1997; 111: 1077-88.

31. Macintyre NR. Muscle dysfunction associated with chronic obstructive pulmonary disease. Respir Care 2006; 51: 840-8.

32. Mador MJ, Bozkanat E, Aggarwal A, Shaffer M, Kufel TJ. Endurance and strength training in patients with COPD. Chest 2004; 125: 2036-45.

33. Maltais F, Simard A-A, Simard C, et al. Oxidative capacity of teh skeletal muscle and lactic acid kinetics during exrcise in normal subjects and in patients with COPD. Am J Respir Crit Care Med 1996; 153: 288-93.

34. Maltais F, Sullivan MJ, LeBlanc $P$, et al. Altered expression of myosin heavy chain in the vastus lateralis muscle in patients with COPD. Eur Respir $J$ 1999; 13: 850-4

35. Molfino NA, Jeffery PK. Chronic obstructive pulmonary disease: Histopathology, inflammation and potential strategies. Pulm Pharmacol Ther 2007; 20 462-72.
36. Nava S, Gayan-Ramirez G, Rollier H, et al. Effect of acute streroid administration on ventilatory and peripheral muscles in rats. Am J Respir Crit Care Med 1996; 153:1888-96.

37. Nici L, Donner C, Wouters E, et al. American Thoracic Society / European Respiratory Society statement on pulmonary rehabilitation. Am J Respir Crit Care Med 2005; 173: 1390-1413.

38. Nowak TJ, Handford AG. Pathophysiology. Concepts and Applications for Health Care Professionals. New York: McGraw-Hill, 2004.

39. O'Donnell DE. Ventilatory limitations in chronic obstructive pulmonary disease. Med Sci Sports Exerc 2001; 33: S647-S655.

40. Ortega F, Toral J, Cejudo $\mathrm{P}$, et al. Comparison of effects of strength and endurance training in patients with chronic obstructive pulmonary disease. Am J Respir Crit Care Med 2002; 166: 669-74.

41. Pinho RA, Chiesa D, Mezzomo KM, et al. Oxidative stress in chronic obstructive pulmonary disease patients submitted to a rehabilitation program. Respir Med 2007; 101: 1830-35

42. Puhan MA, Schunemann HJ, Frey M, Schaplatz M, Bachmann LM. How should COPD patients exercise during respiratory rehabilitation? Comparison of exercise modalities and intensities to treat skeletal muscle dysfunction. Thorax 2005; 60: 367-375.

43. Remels $A H$, Schrauwen $P$, Broekhuizen $R$, et al. Peroxisome proliferatoractivated receptor expression is reduced in skeletal muscle in COPD. Eur Respir J 2007; 30(2): 245-52.

44. Ries AL, Bauldoff GS, Carlin BW, et al. Pulmonary rehabilitation. Joint ACCP/AACVPR Evidence based clinical practice guidelines. Chest 2007; 131: 4S-42S.

45. Rodriguez-Roisin R. The airway pathophysiology of COPD: Implications for treatment. J Chronic Obstruct Pulm Dis 2005; 2: 253-62.

46. Russell AP, Somm E, Debigare $R$, et al. COPD results in a reduction in UCP3 long mRNA and UCP3 protein content in Types I and IIA skeletal muscle fibres. J Cardiopulm Rehabil 2004; 24: 332-9.

47. Satta A, Migliori GB, Spanevello A, et al. Fibre types in skeletal muscle of chronic obstructive pulmonary disease patients related to respiratory function and exercise tolerance. Eur Respir J 1997; 10 (12): 2853-60.

48. Simoneau JA, Kelley DE. Altered glycolytic and oxidative capacities of skeletal muscle contribute to insulin resistance in NIDDM. J Appl Physiol 1997 83: 166-71.

49. Simpson K, Killian K, McCartney N, Stubbimg DG, Jones NL. Randomised controlled trial of weightlfting exercise in patients with chronic airflow limitation. Thorax 1992; 47: 70-5.

50. Spruit MA, Gosselink R, Troosters T, De Paepe K, Decramer M. Resistance versus endurance training in patients with COPD and peripheral muscle weakness. Eur Respir J 2002; 19: 1072-7078.

51. Spurway N, Wackerhage H. Genetics and Molecular Biology of Muscle Adaptation. London: Churchill Livingstone, 2006.

52. Storer TW. Exercise in chronic pulmonary disease: resistance exercise prescription. Med Sci Sports Exerc 2001; 33:S680-S686.

53. Supinski GS, Callahan L. Free radical-mediated skeletal muscle dysfunction in inflammatory conditions. J Appl Physiol 2007; 102: 2056-63.

54. Trenerry MK, Carey KA, Ward AC, Cameron-Smith D. STAT3 signaling is activated in human skeletal muscle following acute resistance exercise. $J$ Appl Physiol 2007; 102: 1483-89.

55. Troosters T. Short-and long-term effects of outpatient rehabilitation in patients with chronic obstructive pulmonary disease: A randomised trial. $\mathrm{Am} J$ Med 2000; 109: 207-12.

56. Troosters T, Casaburi R, Gosselink R, Decramer M. Pulmonary rehabilitation in chronic obstructive pulmonary disease. Am J Respir Crit Care Med 2005 172: $19-38$.

57. Troosters T, Gosselink R, Decramer M. Chronic obstructive pulmonary disease and chronic heart failure. Two muscle diseases? J Cardiopulm Rehabil 2004; 24: $137-45$.

58. Troosters T, Gosselink R, Langer D, Decramer M. Pulmonary rehabilitation in chronic obstructive pulmonary disease. Respir Med 2007; 3: 57-64.

59. Winett RA, Carpinelli RN. Potential health-related benefits of resistance training. Prev Med 2001; 33: 503-13.

60. Wouters EFM. Minimal clinically important differences in COPD: body mass index and muscle strength. J Chronic Obstruc Pulm Dis 2005; 2: 149-55.

61. Wright PR, Heck H, Langenkamp H, Franz KH, Weber U. Influence of resistance training on pulmonary function and performance measures of patients with COPD. Pneumologie 2002; 56: 413-7.

62. Zierath JR, Hawley JA. Skeletal muscle fiber type: Influence on contractile and metabolic properties. PLoS Biol 2004; 2: 1523-27. 